University of Nebraska - Lincoln

DigitalCommons@University of Nebraska - Lincoln

Faculty Publications from the Harold W. Manter Laboratory of Parasitology

8-1992

\title{
Parasiticidal Effect of Chemotherapy in Alveolar Hydatid Disease: Review of Experience with Mebendazole and Albendazole in Alaskan Eskimos
}

\author{
J. F. Wilson \\ Alaska Native Medical Center \\ Robert L. Rausch \\ University of Washington, rausch@uw.edu \\ B. J. McMahon \\ United States Centers for Disease Control \\ P. M. Schantz \\ United States Centers for Disease Control
}

Follow this and additional works at: https://digitalcommons.unl.edu/parasitologyfacpubs

Part of the Parasitology Commons

Wilson, J. F.; Rausch, Robert L.; McMahon, B. J.; and Schantz, P. M., "Parasiticidal Effect of Chemotherapy in Alveolar Hydatid Disease: Review of Experience with Mebendazole and Albendazole in Alaskan Eskimos" (1992). Faculty Publications from the Harold W. Manter Laboratory of Parasitology. 371. https://digitalcommons.unl.edu/parasitologyfacpubs/371

This Article is brought to you for free and open access by the Parasitology, Harold W. Manter Laboratory of at DigitalCommons@University of Nebraska - Lincoln. It has been accepted for inclusion in Faculty Publications from the Harold W. Manter Laboratory of Parasitology by an authorized administrator of DigitalCommons@University of Nebraska - Lincoln. 


\title{
Parasiticidal Effect of Chemotherapy in Alveolar Hydatid Disease: Review of Experience with Mebendazole and Albendazole in Alaskan Eskimos
}

\author{
J. F. Wilson, R. L. Rausch, B. J. McMahon, \\ and P. M. Schantz
}

\author{
From the Departments of Surgery and Medicine, Alaska Native Medical \\ Center, Anchorage, Alaska; the Department of Comparative Medicine. \\ School of Medicine, University of Washington, Seattle, Washington; and \\ the Parasitic Disease Division, Centers for Disease Control, \\ Atlanta, Georgia
}

\begin{abstract}
Evidence that the larval stage of Echinococcus multilocularis in humans is killed by chemotherapy is presented in a review of our 17-year experience with treatment of alveolar hydatid disease in Alaska. The efficacy of chemotherapy was assessed with use of an in vivo assay of parasite viability by means of inoculation of voles, immunohistochemical tests, and histopathologic findings. Of 14 tests performed for nine patients, 12 in vivo assays $(86 \%)$ were negative after chemotherapy, while only two $(17 \%)$ of 12 vole tests for seven untreated patients were negative. Regression or arrest of growth of metastatic and primary hepatic lesions, together with their partial-to-complete calcification and prolonged survival times has been observed among patients treated with the benzimidazole compounds. For six who received appropriate chemotherapy, treatment has been discontinued for an average of 4.6 years (range, 3-7 years) without an increase in lesion size or other evidence of reactivation.
\end{abstract}

Alveolar hydatid disease (AHD), caused by the larval stage of the cestode Echinococcus multilocularis, is a serious health problem among Eskimos in northwestern Alaska, as well as in various populations in Eurasia. E. multilocularis is indigenous to the arctic tundra, where arctic foxes and small rodents (voles and lemmings) serve as the final and intermediate hosts. The disease has an extensive distribution in the northern hemisphere, but in North America most autochthonous cases of AHD have been diagnosed in Eskimos in northwestern Alaska. Although good results have been achieved in cases of resectable lesions, before $198681 \%$ of patients in Alaska had nonresectable lesions at the time of diagnosis. In a report of 1,411 operations for AHD performed in the Commonwealth of Independent States, Zhuravlev [1] also found the resectability rate to be low (18\%). These findings clearly reflect the need for an alternate method of treatment of AHD.

E. multilocularis was first identified in the Western Hemisphere on St. Lawrence Island, Alaska, in 1951 [2] (a few earlier cases of AHD were diagnosed retrospectively). Thus far 70 autochthonous cases of AHD have been diagnosed in North America, and all but two have occurred among Eski-

Received 5 February 1991; revised 19 December 1991.

The use of trade names is for identification only.

Financial support: This work was supported in part by the National Institute of Allergy and Infectious Disease (AI 15172); Smith Kline \& French Laboratories; and the Indian Health Service, U.S. Public Health Service (Research Proposal 1980/90).

Reprints or correspondence: Dr. J. F. Wilson, 4821 Mills Drive, Anchorage, Alaska 99508.

Clinical Infectious Diseases 1992;15:234-49

(C) 1992 by The University of Chicago. All rights reserved.

$1058-4838 / 92 / 1502-0003 \$ 02.00$ mos from St. Lawrence Island and from a hyperendemic area on the mainland of northwestern Alaska.

Clinical evaluations of patients, surgeries, and autopsies were conducted at the Alaska Native Medical Center, which, since its establishment in May 1953 in Anchorage, has been the location of the patient-related work concerning AHD. This center is a facility of the U.S. Public Health Service and is the referring institution for a broad-based health delivery system serving the needs of all indigenous peoples in Alaska. The organization includes village clinics staffed by trained Native American health aides and supported by five small, regional field hospitals. Biological and epidemiological investigations concerning E. multilocularis were initiated at the Arctic Health Research Center of the U.S. Public Health Service in 1950 and later undertaken also at the Arctic Investigations Program of the Centers for Disease Control in Anchorage. Consequently, the investigations concerning $E$. multilocularis and AHD have continued without interruption for $\sim 40$ years, and some of the same personnel have been involved for all or most of that period. Aside from basic biological studies, major aspects of this study have included clinical chemotherapy trials and the development of screening and preventive programs [3].

During the early years of this experience, most of the patients with AHD were admitted to the hospital with an abdominal mass or symptoms related to the primary hepatic lesion. For some patients the initial diagnosis was made on the basis of a positive screening serology with use of the indirect hemagglutination method. In 1985 an improved serological technique with use of a specific antigen of E. multilocularis was introduced [4, 5]; and in 1988 field trials were initiated in which a portable ultrasonography (US) unit was used for screening in four high-risk villages, which resulted in 
the diagnosis of four active cases at an early stage of development. Another result of the improved method of screening was the identification of patients with a number of small, calcified hepatic lesions that on further study were found to represent lesions in which the larval cestode had died [6]. Five of these lesions were resected to confirm the diagnosis and to permit testing for viability. Thus far, 26 such cases have been identified and the patients received a clinical diagnosis of inactive AHD; in 12 cases serologies were positive and in 14 the diagnosis was based primarily on the results of computed tomography (CT) or US findings. All such inactive cases are still under investigation and will not be considered further here. The 44 locally acquired cases of active AHD diagnosed in North America form the basis for this review.

After publication of the report of Heath and Chevis [7], widespread interest developed in the use of benzimidazole compounds for the treatment of hydatid disease. Clinical trials of both mebendazole and albendazole have been conducted; however, the results have been inconsistent. Some authors have reported a poor outcome with these drugs in the treatment of cystic hydatid disease [8-11], while others have obtained more optimistic results with regard to the treatment of this condition or AHD [12-25]. The purpose of this paper is to review in detail our 17-year experience with chemotherapy for AHD in Alaska and to present the data that have led us to conclude that $E$. multilocularis can be eradicated by treatment with compounds of the benzimidazole group.

\section{Methods}

The records of all 44 patients with active AHD were reviewed. Tissues were obtained from 14 patients on 26 occasions for in vivo assays for viability. Chemotherapy has been offered to all patients since 1974 (mebendazole through 1984 and albendazole since 1985). Patients scheduled for surgery usually received two or three 28-day courses of albendazole before resection or biopsy of tissues that were to be tested for viability was performed. After a diagnosis of AHD was made and clinical and laboratory data were recorded, chemotherapy was initiated as follows: patients received $40 \mathrm{mg} /(\mathrm{kg} \cdot \mathrm{d})$ of mebendazole (microcrystalline form [Vermox], Janssen, Piscataway, NJ) in three doses with fatty meals [12-14, 26]. Albendazole (Zentel), supplied as 200mg tablets by Smith Kline \& French Laboratories (Philadelphia), was used with the approval of the U.S. Food and Drug Administration after informed consent was obtained. An oral dose of $400 \mathrm{mg}$ was taken b.i.d. with meals according to a protocol in which 28-day courses of therapy are alternated with 14-day drug-free intervals [27] (for convenience, such a course, although consisting of 28 days of therapy given during a 42-day period, will be referred to as 1 month of chemotherapy).

The efficacy of chemotherapy for AHD was assessed by a combination of methods in addition to clinical findings. An in vivo test for viability of the larval cestode has been based on the intraperitoneal inoculation of membranes from patients into red-backed voles (Clethrionomys rutilus [Rodentia: Arvicolidae]). More recently, equally good results have been obtained with northern voles (Microtus oeconomous) and Mongolian gerbils (Meriones unguiculatus) (the redbacked and northern voles are natural intermediate hosts of E. multilocularis on St. Lawrence Island and in major regions of Europe and Asia endemic for AHD). We examined inoculated rodents 3-4 months postinoculation to determine results. The proliferation of vesicles confirmed that the larval cestode was viable.

Tissues for bioassay were obtained by means of surgical or needle biopsy on 14 occasions from nine individuals who had received at least 2 years of therapy with mebendazole or 2 months of therapy with albendazole (table 1). These parameters were based empirically on results of bioassays performed before 1985 (for all patients treated for $\geqslant 24$ months, with one exception, the results were negative) [26]. Since vesicles of the larval cestode in host tissue remain infective for $>1$ week when stored under refrigeration, vesicles obtained at autopsy 2-3 days postmortem were suitable for testing. Untreated patients for whom in vivo tests were performed served as historical controls. Patients who received insufficient chemotherapy, as defined above, are for present purposes described as undertreated. Twelve tests were performed for 10 untreated or undertreated individuals.

The reliability of the in vivo test depends on whether an adequate quantity of membranes from the patient's tissues has been obtained. Material obtained by needle biopsy is the least reliable, since few, if any, membranes may be present. In contrast to tissues of $E$. multilocularis that are used for maintaining isolates in the laboratory, also transferred by intraperitoneal inoculation, those obtained from patients are difficult to quantify for in vivo tests. Fully developed larval cestodes from rodents consist of a dense aggregation of microcysts with abundant protoscolices and little or no host tissue. Consequently, uniform 0.1 -g samples are readily obtainable. In humans, however, sterile vesicles (lacking protoscolices) that are usually of small size are dispersed in a dense matrix of collagen that has replaced hepatic tissue. In collecting material for inoculation, slices of the lesion are examined for cavities containing membranes (figure 1), which are translucent and often folded [28]. The membranes are removed by means of fine-pointed forceps and placed in saline, after which aliquots are prepared for inoculation into the rodents (three rodents were routinely inoculated, unless the quantity of membranes was insufficient).

When normally developed larval E. multilocularis consists of great numbers of closely apposed, interconnected vesicles, each made up of an external nonviable layer, the laminated membrane, and an internal layer of germinal tissue from which brood capsules and protoscolices arise. When found 
Table 1. Efficacy of chemotherapy determined by in vivo assay of parasite viability in voles for untreated and treated patients with alveolar hydatid disease.

\begin{tabular}{|c|c|c|c|c|c|c|c|}
\hline \multirow[b]{2}{*}{ Treatment } & \multirow{2}{*}{$\begin{array}{l}\text { Patient } \\
\text { no.* }\end{array}$} & \multirow{2}{*}{$\begin{array}{l}\text { Source of } \\
\text { tissue }\end{array}$} & \multirow{2}{*}{$\begin{array}{c}\text { Date } \\
\text { tissue } \\
\text { obtained }\end{array}$} & \multirow{2}{*}{$\begin{array}{c}\text { No. of } \\
\text { months of } \\
\text { chemotherapy }\end{array}$} & \multicolumn{2}{|c|}{$\begin{array}{l}\text { Results of assay } \\
\text { (no. of voles) }\end{array}$} & \multirow{2}{*}{$\begin{array}{l}\text { No. of } \\
\text { negative } \\
\text { tests (\%) }\end{array}$} \\
\hline & & & & & Growth & $\begin{array}{l}\text { No } \\
\text { growth }\end{array}$ & \\
\hline \multirow[t]{8}{*}{ Untreated } & 26 & Resection & $10 / 71$ & 0 & 2 & 1 & \\
\hline & 30 & Resection & $8 / 73$ & 0 & 2 & 1 & \\
\hline & 4 & Surgical biopsy & $11 / 74$ & 0 & 1 & 2 & \\
\hline & $\mathrm{w}^{\dagger}$ & Resection & $10 / 77$ & 0 & 3 & 2 & \\
\hline & 35 & Surgical biopsy & $11 / 80$ & 0 & 0 & 2 & \\
\hline & 38 & Resection & $6 / 84$ & 0 & 2 & 0 & \\
\hline & 51 & Surgical biopsy & $5 / 87$ & 0 & 2 & 0 & \\
\hline & \multicolumn{7}{|c|}{ Undertreated } \\
\hline \multicolumn{7}{|c|}{ Mebendazole $(<2$ y) } & \\
\hline & 5 & Needle biopsy & $2 / 77$ & 6 & 1 & 0 & \\
\hline & 5 & Surgical biopsy & $2 / 77$ & 6 & 1 & 1 & \\
\hline & 34 & Surgical biopsy & $2 / 82$ & 15 & 1 & 3 & \\
\hline & & & & & & & $1(10)$ \\
\hline \multicolumn{8}{|c|}{ Albendazole $(<2 \mathrm{mo})$} \\
\hline & 42 & Surgical biopsy & $10 / 85$ & 1 & 0 & 2 & \\
\hline & 42 & Surgical biopsy & $2 / 88$ & 1 & 1 & 1 & \\
\hline & & & & & & & $2(17)$ \\
\hline \multicolumn{8}{|l|}{ Treated } \\
\hline \multicolumn{8}{|c|}{ Mebendazole $(\geqslant 2$ y) } \\
\hline & 4 & Needle biopsy & $11 / 78$ & 48 & 1 & 1 & \\
\hline & 1 & Surgical biopsy & $12 / 78$ & 37 & 0 & 1 & \\
\hline & 1 & Surgical biopsy & $2 / 80$ & 62 & 0 & 3 & \\
\hline & 34 & Surgical biopsy & $11 / 82$ & 24 & 0 & 1 & \\
\hline & 1 & Autopsy & $4 / 84$ & 108 & 0 & 2 & \\
\hline & 34 & Autopsy & $10 / 84$ & 37 & 0 & 2 & \\
\hline & 3 & Autopsy & $3 / 85$ & 123 & 0 & 3 & \\
\hline & 30 & Autopsy & $9 / 85$ & 42 & 0 & 3 & \\
\hline & 4 & Surgical biopsy & $11 / 86$ & 143 & 0 & 2 & \\
\hline & 35 & Surgical biopsy & $-/ 86$ & 72 & 0 & 2 & \\
\hline & 35 & Surgical biopsy & $3 / 90$ & 74 & 0 & 2 & \\
\hline \multicolumn{7}{|c|}{ Albendazole $(\geqslant 2 \mathrm{mo})$} & $10(91)$ \\
\hline & 39 & Surgical biopsy & $5 / 85$ & 2 & 0 & 2 & \\
\hline & 42 & Surgical biopsy & $3 / 90$ & 9 & 1 & 5 & \\
\hline & 60 & Surgical biopsy & $5 / 91$ & 3 & 1 & 2 & \\
\hline
\end{tabular}

NOTE. For seven untreated patients, seven tests were performed; for nine undertreated patients who received mebendazole, 10 tests were performed; for 10 undertreated patients who received albendazole, 12 tests were performed; for six treated patients who received mebendazole, 11 tests were performed; and for nine treated patients who received albendazole, 14 tests were performed.

* Patient no. corresponds with that in text [13].

+ Patient from Wisconsin.

in humans, however, the organism's germinal layer is very thin and usually not discernible by light microscopy. In active lesions of AHD, all germinal tissue in the peripheral zone of proliferation is presumably viable; it is from that zone that surgical and needle biopsy specimens are obtained. Vesicles in such tissues consist of laminated membrane, presumably with a thin layer of germinal tissue which, when inoculated into rodents, undergoes proliferation and ulti- mately produces protoscolices. We have routinely inoculated 10-15 small vesicles, judged from experience to be adequate for producing vesicles in an individual rodent (figure 2 ). The minimal number of cells required for proliferation is unknown, but Furuya [29] determined that growth occurred when $10^{7}$ undifferentiated (germinal) cells from tissue cultures were inoculated into cotton rats (Sigmodon hispidus).

The germinal membrane in paraffin sections is stained by 


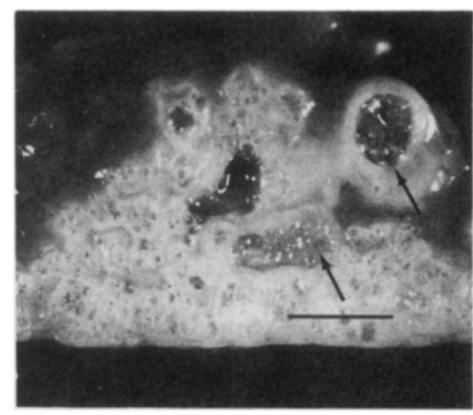

Figure 1. Cut surface of a typical lesion of AHD in the liver (case $60)$. Arrows indicate cavities filled by membranes of the larval $E$. multilocularis. The scale bar has a value of $5 \mathrm{~mm}$.

means of the avidin-biotin immunohistochemical (ABC) method [30]. With this technique active lesions can be distinguished from those in which the larval cestode has died spontaneously, but it appears to be of limited value in assessing the effect of long-term mebendazole therapy. In such cases, positive staining has been observed for scattered vesicles which, as indicated by other evidence, were nonviable [30].

It is often difficult to determine whether the larval cestode in lesions is dead or alive when it is assessed by means of the usual histopathologic methods. The laminated membrane may persist even in totally calcified lesions in which the larval cestode was evidently nonviable for $10-30$ years [6]. Nonetheless, such membranes in decalcified tissues stain strongly when the periodic acid-Schiff method is used and often do not differ in staining characteristics from membranes taken from active lesions. The presence of the laminated membrane in nonactive lesions may account for a persistent antibody response. Since protoscolices are very rarely produced in humans (they were found in a metastatic lesion in the brain in only one of our cases), viability cannot be established on the basis of observation of flame cells or by less reliable methods of staining [31]. Signs of degenerative changes in laminated membranes and the characteristics of the cellular response are useful in distinguishing nonviable vesicles.

\section{Clinical Experience}

The effect that chemotherapy has had on the clinical course of the disease was also evaluated. Among 31 patients for whom the diagnosis was made before 1974, six were cured with surgical resection and two underwent incomplete resections. Twenty-three patients with nonresectable disease initially received no chemotherapy. Early in this experience five cases were excluded from analysis because clinical data were insufficient for assessment (data on these five cases were included only with regard to survival). Two cases in which incomplete resections were performed and one recent case (case 42 in which severe undertreatment occurred be- cause of noncompliance with therapy) are added to the remaining 18 untreated cases to give a total of 21 patients who had active untreated or undertreated lesions and who were observed over time. They serve as the historical controls to be compared with 13 patients who received chemotherapy (table 2). (Eleven active cases were diagnosed after 1974 when chemotherapy trials were initiated; of these, data from three are not included because the patients died of causes unrelated to AHD before they had received 2 years of mebendazole therapy.) Five patients in the untreated group eventually received chemotherapy (cases $1,2,3,30$, and 42), and data from these cases appear in both the treated and untreated categories, resulting in analysis of 34 cases.

In this study the sizes of untreated hepatic lesions were largely determined during physical examination by measuring the palpable liver edge or hepatic mass below the costal margin. Before 1975 the only means for monitoring the progress of lesions was by physical examination, and thus it was customary for the physician to conduct thorough examinations and to record results at the time of each clinic visit. Most of the examinations were performed by one of the authors over the period of 1961 to the present. Data from physical examinations represent, in nearly all cases, the average measurements derived from several cases. Lesions of treated cases were more precisely monitored by $\mathrm{CT}$ and US, imaging techniques not previously available. Overall progression was assessed by measuring the change in lesion size as determined by physical examination or imaging methods or on the basis of extension of disease, the development of endstage disease or metastases, and other clinical criteria.

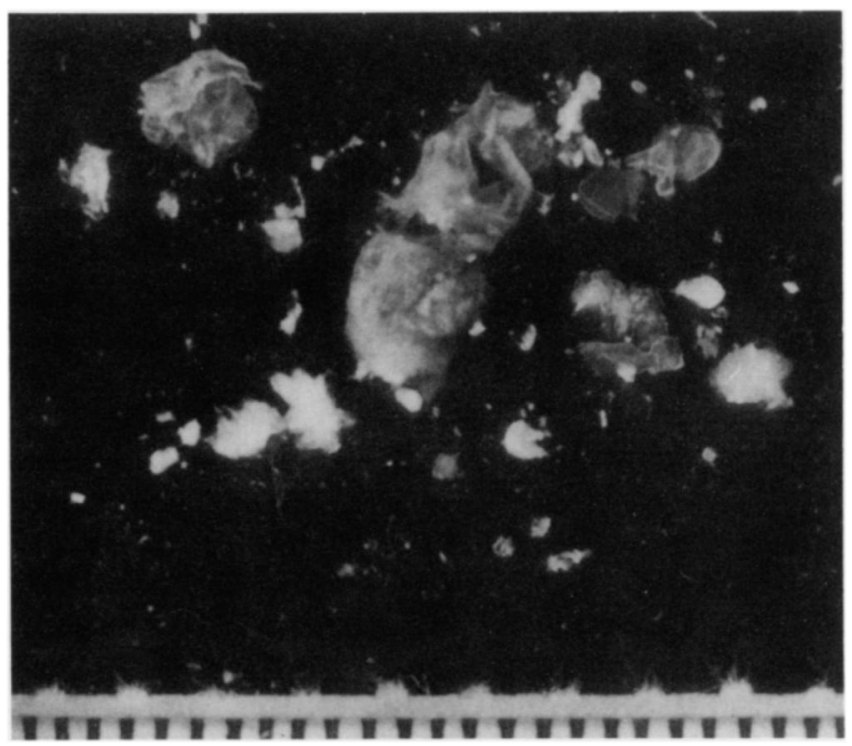

Figure 2. Appearance of vesicles of E. multilocularis taken from tissue shown in figure 1. The quantity shown was sufficient for inoculating three voles and inducing proliferation. Each space has a value of $1 \mathrm{~mm}$. 
Table 2. Summary of clinical data on patients with untreated and treated alveolar hydatid disease.

\begin{tabular}{|c|c|c|c|c|c|c|c|c|c|c|}
\hline \multirow[b]{3}{*}{$\begin{array}{l}\text { Case } \\
\text { no./age } \\
\text { (y) }\end{array}$} & \multirow[b]{3}{*}{ Date } & \multirow[b]{3}{*}{$\begin{array}{c}\text { Years } \\
\text { observed }\end{array}$} & \multicolumn{7}{|c|}{ Status of lesion over time } & \multirow[b]{3}{*}{ Clinical findings } \\
\hline & & & \multirow[b]{2}{*}{$\begin{array}{l}\text { Initial } \\
\text { size }\end{array}$} & \multirow[b]{2}{*}{$\begin{array}{l}\text { Final } \\
\text { size* }\end{array}$} & \multicolumn{5}{|c|}{ Progression } & \\
\hline & & & & & Growth $^{\dagger}$ & Extension $^{\ddagger}$ & Metastases & ESD & $\begin{array}{l}\text { Summary } \\
\text { of } \\
\text { progression }\end{array}$ & \\
\hline \multicolumn{11}{|c|}{$\begin{array}{l}\text { Untreated and } \\
\text { undertreated } \\
\text { patients }\end{array}$} \\
\hline $1 / 34^{8}$ & $12 / 66$ & 8 & 5 & 12 & + & - & $\begin{array}{l}\text { Lung, } \\
\text { mediastinum, } \\
\text { lymph nodes }\end{array}$ & + & $\mathrm{OP}$ & $\begin{array}{l}\text { Hepatic abscess }(20 \times 25 \mathrm{~cm}) \text {; } \\
\text { then mediastinal and } \\
\text { pulmonary mets and ESD }\end{array}$ \\
\hline $2 / 67^{8}$ & $12 / 69$ & 5 & 0 & $1.4^{\prime \prime}$ & + & - & - & + & OP & $\begin{array}{l}\text { Rapidly enlarging widespread } \\
\text { pulmonary mets; ESD }\end{array}$ \\
\hline $3 / 56^{8}$ & $6 / 71$ & 4 & 4 & 13 & + & + & Brain, retina & + & SP & $\begin{array}{l}\text { Lesion }(26 \mathrm{~cm}) \text { with extension } \\
\text { through diaphragm; ESD, } \\
1969\end{array}$ \\
\hline $30 / 65^{8}$ & $3 / 73$ & 7 & 0 & $5 \times 8.4$ & + & - & - & - & OP & $\begin{array}{l}\text { Lesion }(2 \mathrm{~cm}) \text { "resected for } \\
\text { cure"; increasing serum } \\
\text { antibody titers and } \\
\text { diagnosis of a recurrent } 5 \times \\
\text { 8-cm lesion on CT, 10/80 }\end{array}$ \\
\hline $42 / 20^{8}$ & $4 / 85$ & 2.7 & 7.7 & 9.8 & + & - & - & - & OP & $\begin{array}{l}\text { Lesion }(8 \mathrm{~cm}) \text { inadequately } \\
\text { treated, 1985-1988; } \\
\text { noncompliance with } \\
\text { chemotherapy and low } \\
\text { serum level of ALBZ led to } \\
\text { reactivation }\end{array}$ \\
\hline $23 / 52^{\#}$ & $1 / 47$ & 11 & 2 & 10 & + & + & - & + & SP & $\begin{array}{l}\text { Duodenal mass and mets to } \\
\text { liver on surgery, 1947; } \\
\text { massive hepatic abscess; } \\
\text { marsupialization }\end{array}$ \\
\hline $10 / 30^{\#}$ & $1 / 50$ & 2.5 & ND & ND & + & - & Brain & + & SP & $\begin{array}{l}\text { Mets to brain; craniotomy, } \\
11 / 50 ; \text { protoscolices found } \\
\text { in microcysts of brain; died }\end{array}$ \\
\hline $25 / 30^{\#}$ & 1950 & 13 & 15 & ND & + & + & - & + & SP & $\begin{array}{l}\text { Lesion }(15 \mathrm{~cm}) \text { partially } \\
\text { excised, 1950; pain and } \\
\text { jaundice, 1954; hepatocolic } \\
\text { fistula and fatal } \\
\text { hemorrhage, } 1963\end{array}$ \\
\hline $24 / 54^{\#}$ & $7 / 57$ & 1 & 10 & & + & - & Brain & + & SP & $\begin{array}{l}\text { Hepatomegaly, abdominal } \\
\text { mass }(10 \mathrm{~cm}) \text {; CNS } \\
\text { symptoms; fatal brain mets }\end{array}$ \\
\hline $17 / 74^{\#}$ & $5 / 58$ & 0.1 & $7 \times 10$ & & + & + & Lung & + & SP & $\begin{array}{l}\text { Jaundice; abdominal mass } \\
\text { diagnosed as cancer; } \\
\text { massive ESD with extension } \\
\text { into duodenum; mets to } \\
\text { lung and fatal hemorrhage, } \\
1963\end{array}$ \\
\hline $19 / 53^{8}$ & $2 / 59$ & 13 & 0 & 8 & + & + & - & + & SP & $\begin{array}{l}\text { Large hepatic mass with } \\
\text { extension into IVC; } \\
\text { anasarca; death } 13 \text { y after } \\
\text { diagnosis }\end{array}$ \\
\hline $33 / 22^{8}$ & $2 / 60$ & 3 & 0 & $14 \times 16^{* *}$ & + & + & - & + & $\mathrm{OP}$ & $\begin{array}{l}\text { Jaundice; stony-hard mass ( } 8 \\
\times 12 \mathrm{~cm}) \text { of left lobe } \\
\text { resected; recurrence within } \\
3 \text { y with massive lesion }(14 \\
\times 16 \mathrm{~cm}) \text { extending through } \\
\text { diaphragm; biliary } \\
\text { obstruction; death }\end{array}$ \\
\hline
\end{tabular}


Table 2. (Continued)

\begin{tabular}{|c|c|c|c|c|c|c|c|c|c|c|}
\hline \multirow[b]{3}{*}{$\begin{array}{l}\text { Case } \\
\text { no./age } \\
\text { (y) } \\
\end{array}$} & \multirow[b]{3}{*}{ Date } & \multirow[b]{3}{*}{$\begin{array}{c}\text { Years } \\
\text { observed }\end{array}$} & \multicolumn{7}{|c|}{ Status of lesion over time } & \multirow[b]{3}{*}{ Clinical findings } \\
\hline & & & \multirow[b]{2}{*}{$\begin{array}{l}\text { Initial } \\
\text { size }\end{array}$} & \multirow[b]{2}{*}{$\begin{array}{l}\text { Final } \\
\text { size* }\end{array}$} & \multicolumn{5}{|c|}{ Progression } & \\
\hline & & & & & Growth $^{\dagger}$ & Extension ${ }^{\ddagger}$ & Metastases & ESD & $\begin{array}{l}\text { Summary } \\
\text { of } \\
\text { progression }\end{array}$ & \\
\hline $11 / 65^{8}$ & 1960 & 4.5 & 6 & 17 & + & + & - & + & SP & $\begin{array}{l}\text { Diagnosis by serosurvey; } \\
\text { progression to ESD; liver } \\
\text { enlarged (from } 6 \mathrm{~cm} \text { to } 17 \\
\text { cm below costal margin); } \\
\text { IVC obstruction; anasarca } \\
\text { and death }\end{array}$ \\
\hline $14 / 51^{\S}$ & $11 / 60$ & 10.4 & 3 & 8 & + & - & Brain & + & SP & $\begin{array}{l}\text { Diagnosis by serology; } \\
\text { increasing liver size for } 11 \\
\text { y; fatal brain mets }\end{array}$ \\
\hline $16 / 81^{\dagger+}$ & $6 / 62$ & 8.6 & 10 & $0^{\ddagger \ddagger}$ & - & + & - & - & $\mathbf{R}$ & $\begin{array}{l}\text { Spontaneous drainage of large } \\
\text { abscess by fistula to skin } \\
\text { (persisted } 8 \text { y); died of other } \\
\text { causes }\end{array}$ \\
\hline $12 / 53^{8}$ & $8 / 62$ & 0.2 & $10 \times 7$ & & + & + & - & + & SP & $\begin{array}{l}\text { Jaundice }(3 \mathrm{mo}) \text {; surgical } \\
\text { exploration for ESD; central } \\
\text { lesion }(10 \times 7 \mathrm{~cm}) \text { with } \\
\text { obstruction of IVC }\end{array}$ \\
\hline $15 / 28^{8}$ & $10 / 67$ & 0.1 & ND & ND & + & - & Brain & + & SP & $\begin{array}{l}\text { Seizures, craniotomy for } \\
\text { "brain abscess"; died } 1 \text { mo } \\
\text { later }\end{array}$ \\
\hline $9 / 62^{8}$ & $12 / 67$ & 7 & 0 & 8 & + & - & - & - & $\mathrm{OP}$ & $\begin{array}{l}\text { Liver scan (negative), 1967; } \\
\text { repeated, } 1972 \text { (multiple } \\
\text { hepatic lesions); died with } \\
\text { advanced AHD }\end{array}$ \\
\hline $7 / 53^{+\dagger}$ & $12 / 63$ & 11 & 3 & 13 & + & - & - & + & $\mathrm{SP}$ & $\begin{array}{l}\text { Nodular liver on physical } \\
\text { examination; increasing size } \\
\text { of liver; died of pneumonia }\end{array}$ \\
\hline $8 / 82^{8}$ & 1970 & 5 & 2 & 10 & + & - & - & + & SP & $\begin{array}{l}\text { Diagnosis by serosurvey; } \\
\text { increasing liver size; died of } \\
\text { ESD; lesion }(16 \mathrm{~cm}) \text { at } \\
\text { autopsy }\end{array}$ \\
\hline $6 / 74^{8}$ & $2 / 71$ & 6 & 4 & 12 & + & + & - & + & SP & $\begin{array}{l}\text { Diagnosis by serology; } \\
\text { progressed to ESD; IVC } \\
\text { obstructed; anasarca }\end{array}$ \\
\hline \multicolumn{11}{|c|}{$\begin{array}{l}\text { Treated } \\
\qquad \text { (mebendazole) }\end{array}$} \\
\hline $1 / 42^{88}$ & $12 / 74$ & 17.3 & 21 & $8^{\ddagger \ddagger}$ & - & - & - & - & OR & $\begin{array}{l}\text { Regression of substernal mets } \\
(26-8 \mathrm{~mm}) \text {; clinically } \\
\text { improved for } 10 \mathrm{y} \text {; died of } \\
\text { late complications of AHD }\end{array}$ \\
\hline $2 / 62^{1|1|}$ & $1 / 75$ & 21.9 & $1.4^{11}$ & $1.4^{11}$ & - & - & - & - & OR & $\begin{array}{l}\text { Rapid growth of pulmonary } \\
\text { mets arrested by MBZ (1/75 } \\
\text { to } 3 / 86) ; 27 \text { of } 30 \\
\text { pulmonary nodules and } \\
\text { primary hepatic lesions } \\
\text { totally calcified, appear } \\
\text { inactive on CT }(5 / 89) ; \\
\text { clinically well }\end{array}$ \\
\hline $3 / 61^{88}$ & $1 / 75$ & 13.7 & 26 & $8^{\ddagger \ddagger}$ & - & - & Brain, retina & - & $\mathbf{R}$ & See table 3 \\
\hline $30 / 72^{\prime \prime I I}$ & $10 / 80$ & 12.1 & $5 \times 8.4$ & $2 \times 4^{* *}$ & - & - & - & - & OR & See table 3 \\
\hline $4 / 43^{1 \mid 1 I}$ & $12 / 74$ & 16.9 & 20 & 10.5 & - & - & - & - & OR & See table 3 \\
\hline $5 / 65^{\prime \prime \prime I}$ & $4 / 76$ & 15.5 & $7 \times 10$ & $7 \times 10$ & - & - & - & - & $\mathrm{U}$ & $\begin{array}{l}\text { Diagnosed by serology; vole } \\
\text { assay positive after } \\
\text { chemotherapy ( } 5 \mathrm{mo}) \text {; no } \\
\text { increase in lesion size for } \\
8.5 \mathrm{y} \text {; therapy with MBZ } \\
\text { ( } 8 / 78 \text { to } 2 / 85) \text {; strongly } \\
\text { positive serology now } \\
\text { negative for } 5 \mathrm{y}\end{array}$ \\
\hline
\end{tabular}


Table 2. (Continued)

\begin{tabular}{|c|c|c|c|c|c|c|c|c|c|c|}
\hline \multirow[b]{3}{*}{$\begin{array}{l}\text { Case } \\
\text { no./age } \\
(\mathrm{y}) \\
\end{array}$} & \multirow[b]{3}{*}{ Date } & \multirow[b]{3}{*}{$\begin{array}{c}\text { Years } \\
\text { observed }\end{array}$} & \multicolumn{6}{|c|}{ Status of lesion over time } & \multirow{2}{*}{$\begin{array}{c}\text { Summary } \\
\text { of } \\
\text { progression }\end{array}$} & \multirow[b]{3}{*}{ Clinical findings } \\
\hline & & & \multirow[b]{2}{*}{$\begin{array}{c}\text { Initial } \\
\text { size }\end{array}$} & \multirow[b]{2}{*}{$\begin{array}{l}\text { Final } \\
\text { size* }\end{array}$} & \multicolumn{5}{|c|}{ Progression } & \\
\hline & & & & & Growth $^{\dagger}$ & Extension $^{\ddagger}$ & Metastases & ESD & & \\
\hline $34 / 50^{\text {s8 }}$ & $11 / 80$ & 3.9 & $7 \times 10$ & 9.7 & - & - & - & - & OR & $\begin{array}{l}\text { Therapy with } \mathrm{MBZ} \text { (11/80 to } \\
\text { 12/83); growth of two } \\
\text { central lesions arrested for } \\
4 \text { y; obstruction of common } \\
\text { bile duct; external tube } \\
\text { drainage for } 10 \text { mo; biliary } \\
\text { cirrhosis and portal } \\
\text { hypertension; died }\end{array}$ \\
\hline $35 / 56^{\dagger \dagger}$ & $10 / 80$ & 9.5 & $5.4 \times 6.6$ & & $4.7 \times 6$ & - & - & - & OR & See table 3 \\
\hline \multicolumn{11}{|c|}{$\begin{array}{l}\text { Treated } \\
\quad \text { (albendazole) }\end{array}$} \\
\hline $42 / 20^{\prime I I I}$ & $4 / 85$ & 6.6 & 9.8 & 11 & + & - & - & - & $\mathbf{P}$ & See text \\
\hline $39 / 51^{1111}$ & $2 / 85$ & 6.7 & 4.3 & $\mathrm{~S}$ & - & - & - & - & OR & $\begin{array}{l}\text { Diagnosis by serosurvey; after } \\
\text { therapy with ALBZ ( } 2 \mathrm{mo} \text { ) } \\
\text { lesion resected; in vivo } \\
\text { viability assay negative; } \\
\text { postoperative serologies } \\
\text { negative for } 6.5 \mathrm{y}\end{array}$ \\
\hline $51 / 67^{11111}$ & $2 / 87$ & 4.7 & $3.4 \times 4.5$ & $3.5 \times 3.9$ & - & - & - & - & $\mathrm{U}$ & $\begin{array}{l}\text { Lesion }(4 \mathrm{~cm}) \text { found } \\
\text { incidentally on CT, } 2 / 87 \text {; } \\
\text { open biopsy specimen gave } \\
\text { positive vole viability } \\
\text { results; therapy with ALBZ } \\
(3.7 \text { mo); severe dermatitis; } \\
\text { ALBZ discontinued (see } \\
\text { table } 4)\end{array}$ \\
\hline $53 / 33^{1111}$ & $6 / 88$ & 3.3 & $2 \times 4$ & $1.5 \times 3.2$ & - & - & - & - & OR & $\begin{array}{l}\text { Lesion }(2 \times 4 \mathrm{~cm} \text {, mixed } \\
\text { density) found on US; } \\
\text { therapy with ALBZ }(7 \mathrm{mo}) \\
\text { tolerated; resection offered, } \\
\text { declined (see table } 4)\end{array}$ \\
\hline $60 / 53^{1111}$ & $2 / 91$ & 0.7 & $3 \times 3$ & $S$ & & & & & OR & $\begin{array}{l}\text { Suspicious finding on } \\
\text { screening US, } 6 / 88 ; \text { US } \\
\text { negative when repeated } 6 \text { / } \\
89 ; \text { serum antibody titers } \\
\text { elevated, lesion ( } 3 \mathrm{~cm} \text {, } \\
\text { mixed density) found on } \\
\text { CT; ALBZ therapy for } 3 \\
\text { mo; lesion resected } 5 / 91 ; \\
\text { weakly positive results in } \\
\text { one of three voles; } 12 \text { mo } \\
\text { of therapy with ALBZ } \\
\text { scheduled }\end{array}$ \\
\hline
\end{tabular}

NOTE. ESD = end-stage disease; $+=$ occurred; $-=$ did not occur; $\mathrm{OP}=$ objective evidence of progression; mets $=$ metastases; $\mathrm{SP}=$ severe progression; $\mathrm{CT}=$ computed tomography $\mathrm{ALBZ}=$ albendazole; $\mathrm{ND}=$ not determined; $\mathrm{IVC}=$ inferior vena cava; $\mathrm{R}=$ regression; $\mathrm{AHD}=$ alveolar hydatid disease; $\mathrm{OR}=$ objective evidence of regression or negative in vivo assay; $\mathrm{MBZ}=$ mebendazole; $\mathrm{U}=$ unchanged; $\mathrm{P}=$ progression; $\mathrm{S}=$ no evidence of recurrence; and $\mathrm{US}=$ ultrasonography.

* Lesion size or hepatomegaly determined on physical examination, CT, or roentgenography.

${ }^{\dagger}$ If patient died of brain metastasis or overwhelming AHD, growth is presumed.

$\ddagger$ Obstruction of vena cava or portal vein or fistula to the skin, bowel, or pleura.

Patient eventually treated.

" Pulmonary metastases (average of five nodules).

* Death directly related to AHD.

** Size of lesion measured at autopsy.

${ }^{\text {t+ }}$ Died of unrelated causes.

$\ddagger$ Change in size due to drainage of abscess

Died of late complications of AHD; viability assay negative.

III' Alive. 
End-stage disease was defined as that involving a massive lesion (diameter, $>15 \mathrm{~cm}$ or liver edge $>11 \mathrm{~cm}$ below the costal margin), and extension of disease was defined as that causing obstruction of the inferior vena cava, major hepatic bile ducts, or portal vein or the development of fistulae or distant metastases [26]. Progression of disease is severe and unequivocal: if a patient had end-stage disease before the start of chemotherapy and died of late complications of AHD, the case was not described as showing severe progression or as developing end-stage disease while receiving chemotherapy.

\section{Results}

Long-term mebendazole therapy. Eight patients were treated with mebendazole for $\geqslant 2$ years. Of these, tissues were obtained for viability studies from six. A needle biopsy specimen from one patient (case 4) was positive in 1978, 48 months after therapy was initiated. Tissues were evaluated on 10 other occasions from these six patients. Five specimens were obtained at autopsy and five during surgical exploration. The autopsy findings and in vivo results for two of the patients have been previously reported [26]. Table 3 presents a summary of data for the remaining four patients (see also figures 3 and 4 ).

Short-term albendazole therapy. Five patients were treated with albendazole. Two lesions measuring $4.3 \mathrm{~cm}$ and $3 \mathrm{~cm}$ were resected after 58 and 84 days of therapy, respectively. The in vivo assay of resected tissues was negative for the first patient. For the second patient, whose case was recently diagnosed (case 60), proliferation of the larval cestode was observed in one of three voles that were injected. However, the extent of proliferation was very limited - the weight of the metacestode tissue was $<0.1 \mathrm{~g}$, as compared with the usual weight of 5-15 g when untreated membranes are injected. These findings suggest reduced viability of the larval cestode, with growth from only one of the many microcysts injected. Two patients with $4.5-$ and $4-\mathrm{cm}$ lesions were treated with only albendazole for 3.75 months and 7 months, respectively. No increase in lesion size has been observed with CT during 4.7 and 3.3 years of follow-up.

The fifth patient (case 42 ) was a 20 -year-old woman who had an $8-\mathrm{cm}$ nonresectable lesion and who was treated for 10 months with albendazole ( $400 \mathrm{mg}$ b.i.d.) from June 1985 to July 1986 [27]. Although the initial in vivo test performed after 3 months of therapy with albendazole was negative, the case was complicated by both noncompliance and low serum albendazole levels of $310 \mathrm{ng} / \mathrm{mL}$. She had received no more than 1.5 months of appropriate therapy when reactivation with growth of the lesion to $10 \mathrm{~cm}$ occurred. A second series of treatments for 9 months ( $600 \mathrm{mg}$ b.i.d.) arrested growth for 16 months, and peak serum albendazole levels of 1,320 and $2,120 \mathrm{ng} / \mathrm{mL}$ were attained. However, the lesion then increased in size to $11 \mathrm{~cm}$, and results of an in vivo assay were positive. A third series of treatments with albendazole for 9 months was started in February 1990, followed by longterm mebendazole therapy. The size of the lesion has been stable for 21 months and the patient remains asymptomatic, but the long-term prognosis is not clear. Although we believe that this patient has been taking her drugs as directed since 1988, she, very unlike the other patients, has been quite unreliable in many ways. In addition, other factors such as possible drug resistance or inadequate host immunity must be considered as contributing to this delayed treatment failure. This is the only case, in our experience, in which the larval cestode grew during administration of chemotherapy. While it is too early to fully assess this case, we will consider it at this time as one in which inappropriate therapy was administered.

Vole-inoculation studies. Data from our experience with the vole-inoculation method for assessing the viability of the larval cestode of E. multilocularis are presented in table 1 . Among 12 viability assays of tissue from 10 untreated or undertreated patients, $10(83 \%)$ were positive, while only two (17\%) were negative. Of nine treated patients, an assay performed in 1978 of a needle biopsy specimen from one who had received 48 months of mebendazole therapy was positive. Since that time, 11 of 13 consecutive in vivo tests for nine treated patients failed to show growth of the larval cestode ( $79 \%$ negative). Ten of these negative tests involved specimens from patients who had received $\geqslant 2$ years of mebendazole therapy, and one involved specimens from the patients who had received 2 months of preoperative albendazole therapy.

Untreated vs. treated cases. The clinical course of the 29 study cases is summarized in table 2 . Twenty of these were diagnosed before 1974, when mebendazole was introduced. Four cases were diagnosed by serological screening, while 16 patients presented with a mass or symptoms. Among 21 untreated patients, increasing severity of hepatomegaly or lesion size, as determined by physical examination, CT, or direct measurement, was demonstrated in each of the 14 patients that could be assessed (figure 5). Seven patients were excluded: six in whom the size of the lesion could not be determined and one (case 16) in whom a large abscess drained spontaneously, resulting in a decrease in the degree of hepatomegaly. In two cases the disease recurred after performance of what were believed to have been complete surgical resections. The recurrent lesions presumably arose from microscopic, residual material that was not discernible at the time of surgery; the size of the lesions was considered to be zero immediately after surgery. These lesions progressed in size to reach diameters of $14 \mathrm{~cm}$ and $8 \mathrm{~cm}$ within 3 and 7 years, respectively (cases 33 and 30 ).

Drainage procedures or surgical intervention resulted in marked reduction in the size of the hepatic abscess in three cases (cases 1, 3, and 4). However, these changes were unrelated to the effect of chemotherapy and have been excluded 
Table 3. Clinical findings and evidence of nonviability of $E$. multilocularis for patients receiving mebendazole therapy.

\begin{tabular}{|c|c|c|c|}
\hline $\begin{array}{l}\text { Case } \\
\text { no. }\end{array}$ & Clinical findings & Pathological findings & Evidence of nonviability \\
\hline 3 & $\begin{array}{l}\text { End-stage disease at diagnosis }(1971) \text {; } \\
\text { hepatic abscess ( } 7-8 \mathrm{~L}, 18 \times 25 \\
\mathrm{~cm}) \text {; marked clinical improvement } \\
\text { with MBZ therapy, 1975-1985; } \\
\text { pyogenic infection of hepatic } \\
\text { abscess (1977) requiring external } \\
\text { drainage for } 2 \mathrm{y} \text {; retinal metastasis } \\
\text { ( } 3.25 \mathrm{~mm} \text { ) diagnosed (1980); } \\
\text { seizure (1984) led to diagnosis of a } \\
\text { brain met; led active life until } 1 / 85 ; \\
\text { hospitalized, died of sepsis and } \\
\text { renal failure }\end{array}$ & $\begin{array}{l}\text { Extensive AHD of right } \\
\text { lobe of liver and RLL } \\
\text { of lung at autopsy; } \\
\text { brain met }(2.5 \mathrm{~cm}) \\
\text { and subretinal met } \\
(10 \mathrm{~mm}) \text {; vesicles of } \\
\text { E. multilocularis } \\
\text { abundant; } \\
\text { inoculation of three } \\
\text { voles }\end{array}$ & $\begin{array}{l}\text { Negative vole }(\times 3) \text { and } \\
\text { ABC test results; weak } \\
\text { PAS staining; extensive } \\
\text { necrosis of brain lesion; } \\
\text { degenerative changes in } \\
\text { retinal met }\end{array}$ \\
\hline 4 & $\begin{array}{l}\text { Diagnosis by positive serology and } \\
\text { enlarged liver; } 12 \times 20 \text {-cm central } \\
\text { lesion treated with } \mathrm{MBZ}(12 / 74 \\
\text { to } 4 / 87) \text {; abscess decreased from } \\
20 \mathrm{~cm} \text { to } 10 \mathrm{~cm} \text { without drainage; } \\
\text { biliary obstruction requiring } \\
\text { choledochoduodenostomy and } \\
\text { partial resection }(11 / 86) \text { (wall of } \\
\text { lesion was thin, fibrotic with no } \\
\text { matrix); biliary stent requires } \\
\text { changing every } 2-4 \text { mo; patient } \\
\text { remains active and asymptomatic } \\
17 \text { y after diagnosis }\end{array}$ & $\begin{array}{l}\text { Considerable necrosis } \\
\text { of tissue around } \\
\text { laminated } \\
\text { membranes; large } \\
\text { proportion of vesicles } \\
\text { not taking up PAS } \\
\text { stain; great majority } \\
\text { of membranes gave } \\
\text { negative ABC test } \\
\text { results with rare } \\
\text { scattered membranes } \\
\text { positive }\end{array}$ & $\begin{array}{l}\text { Negative vole test results }(\times \\
\text { 2); decrease in lesion size } \\
\text { without drainage and loss } \\
\text { of matrix; no recurrence } \\
4.5 \text { y after MBZ therapy } \\
\text { discontinued }\end{array}$ \\
\hline 30 & $\begin{array}{l}\text { Lesion }(12 \mathrm{~cm}) \text { "resected for cure" } \\
(1973) \text {; increasing serum antibody } \\
\text { titers led to diagnosis of a recurrent } \\
\text { lesion }(5 \times 8 \mathrm{~cm}) \text {; MBZ therapy } \\
42 \text { mo (discontinued } 1 / 85) \text {; died of } \\
\text { cancer of breast, } 9 / 85\end{array}$ & $\begin{array}{l}\text { Metastatic cancer and } \\
\text { E. multilocularis } \\
\text { lesion }(2 \times 2 \times 4 \mathrm{~cm}) \\
\text { on autopsy }\end{array}$ & $\begin{array}{l}\text { Very weak PAS stain uptake } \\
\text { negative } A B C \text { and vole } \\
\text { test results }(\times 3) \text {; decrease } \\
\text { in lesion size }(10 / 80 \text { to } \\
9 / 85 \text {, from } 5 \times 8 \mathrm{~cm} \text { to } 2 \\
\times 4 \mathrm{~cm})\end{array}$ \\
\hline 35 & $\begin{array}{l}\text { Positive serology; CT revealed a } 6.5- \\
\text { cm central hepatic lesion }(10 / 80) ; \\
\text { MBZ therapy (10/80 to } 12 / 86) ; \\
\text { biliary stricture required internal } \\
\text { drainage with stent }(11 / 86 \text { and } 12 / \\
86) \text {; maintained active life and full } \\
\text { employment, then died of } \\
\text { cerebrovascular accident }(4 / 90)\end{array}$ & $\begin{array}{l}\text { Gelatin-like and friable } \\
\text { laminated } \\
\text { membranes in } \\
\text { autopsy tissue }\end{array}$ & $\begin{array}{l}\text { Degenerative changes in } \\
\text { laminated membranes, } \\
\text { negative vole test results } \\
\text { of surgical and autopsy } \\
\text { tissues (1990) }\end{array}$ \\
\hline
\end{tabular}

NOTE. $\quad \mathrm{MBZ}=$ mebendazole; met $=$ metastasis; $\mathrm{AHD}=$ alveolar hydatid disease; $\mathrm{RLL}=$ right lower lobe; $\mathrm{ABC}=$ avidin-biotin immunohistochemical test; $\mathrm{PAS}=$ periodic acid-Schiff; $\mathrm{CT}=$ computed tomography.

from assessment of change in lesion size. In nine treated cases the size of the hepatic lesion has been assessed over time (figure 6), and in three cases metastatic lesions have been monitored by roentgenography, CT, or US (figure 7). The arrest of growth following institution of chemotherapy is well illustrated in cases 1 and 2 . The continued growth of the retinal metastasis in case 3 is possibly explained by poor penetration of mebendazole through the blood-retina barrier. Viability tests of membranes from other lesions in this case were negative. Among the 13 treated patients, eight are living. The lesions in two were resected (cases 39 and 60), and in another (case 42) the status of the lesion is uncertain. In the remaining five, chemotherapy has been discontinued for an average of 4.8 years (range, 3-7 years) without evidence of any increase in lesion size on semiannual or annual CT and US.

Extension of the disease into adjacent structures was observed in 10 of 21 untreated cases (48\%) and consisted of penetration of the diaphragm, formation of a fistula to the skin or bowel, or blockage of the inferior vena cava. No extension of disease was observed in any of our cases after chemotherapy was started. Distant metastases were observed in eight of the 29 cases summarized in table 2 and in one patient not in the study group. Among untreated patients, four 

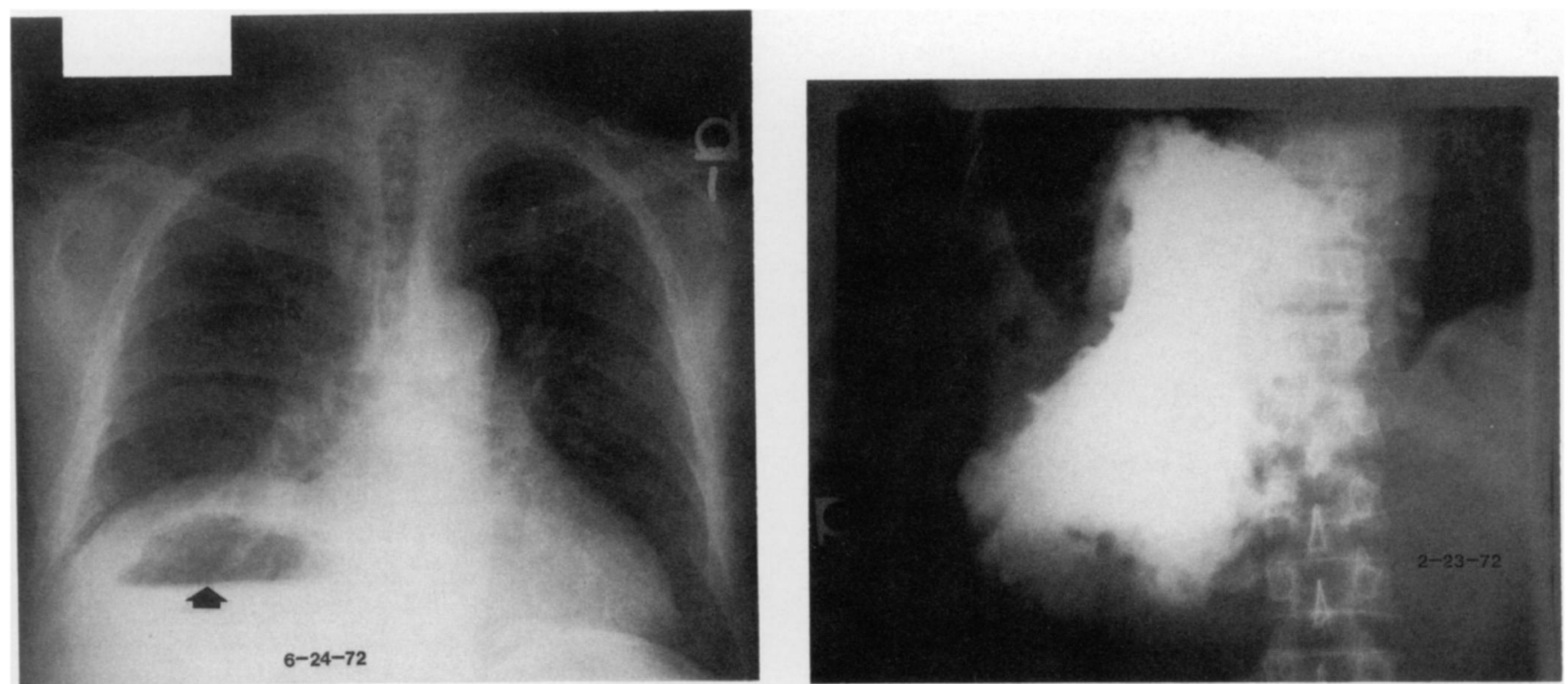

Figure 3. Left, PA chest roentgenogram taken in 1971 of a 58-year-old Eskimo man with a massive hepatic lesion after $3,600 \mathrm{~mL}$ of fluid was aspirated from the lesion and air was injected. Note air-fluid level and elevated diaphragm. Right, flat plate of abdomen after instilling contrast medium (abscess measured $25 \times 18 \times 17 \mathrm{~cm}$ ). (Reprinted with permission from [12]).

developed symptomatic brain metastases and survived, on average, only 0.9 years (range, $1-12$ months) after diagnosis; for two patients incidental autopsy findings of pulmonary or pulmonary and brain metastases were noted. Three patients with metastases received chemotherapy and survived an average of 17.3 years after diagnosis. In cases 1 and 2 there was objective evidence of regression of widespread metastases after mebendazole therapy was started (figure 6). In case 3 brain and retinal metastases were discovered during the period of chemotherapy. However, it is not clear when these metastases actually developed. The brain metastasis in this case behaved very differently from those of untreated patients. No growth was apparent during the year after diagnosis was made by $\mathrm{CT}$, and it did not cause further symptoms or contribute to the patient's death. Tissues from metastases in cases 1 and 3 were not submitted for vole inoculation, but results of periodic acid-Schiff staining of histologic sections and $\mathrm{ABC}$ tests were consistent with severely damaged or nonviable larval cestodes. Growth in the retinal lesion, however, suggests at least that the metastasis was active.

In untreated cases objective evidence of severe progression was observed by roentgenography, CT, or US in six (43\%) of
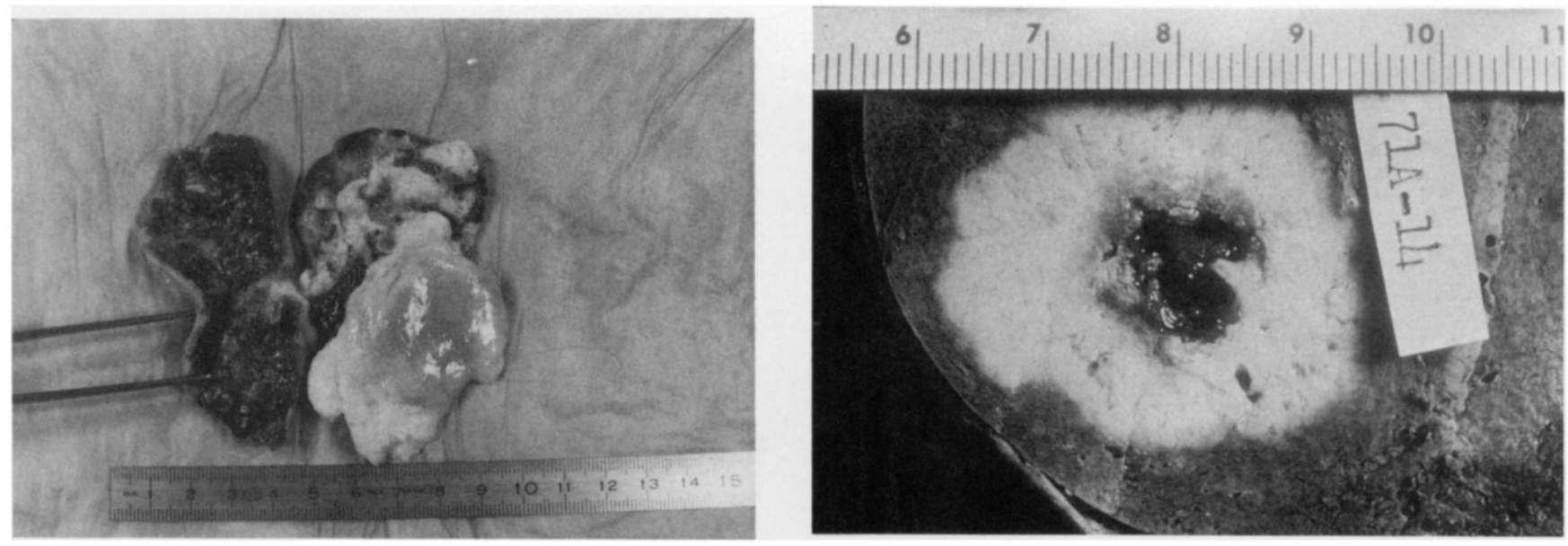

Figure 4. Left, Surgical specimen from internal drainage and unroofing procedure in 1986 after a 43 -year-old man presented with a $20 \times$ $12 \times 12-\mathrm{cm}$ nonresectable hepatic lesion in 1974, for which he received mebendazole ( $3 \mathrm{~g}$ daily for 12 years [case 4]). The thin (2-3 mm) fibrotic wall of the abscess is held in the forceps. Right, the absence of residual matrix contrasts with the characteristic thick matrix of an untreated lesion (autopsy specimen, case 14). 


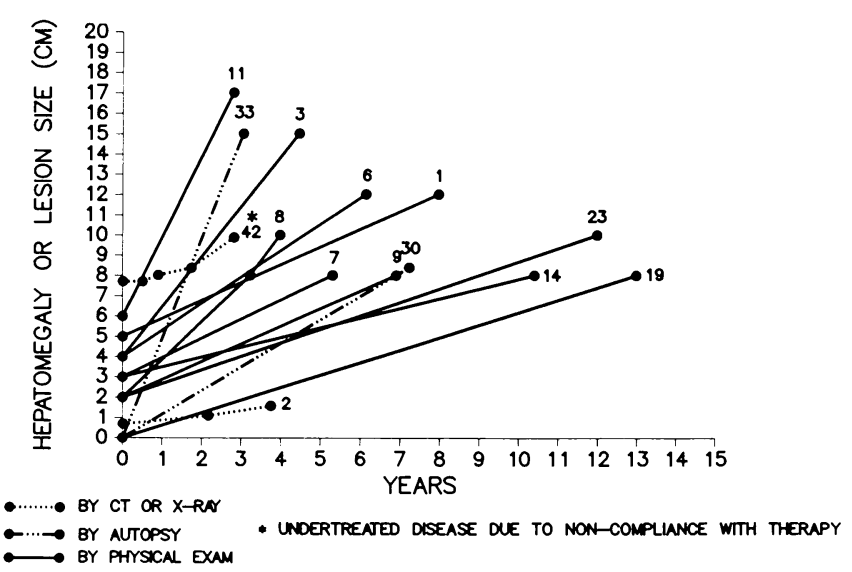

Figure 5. Increase in lesion size or hepatomegaly over time in untreated or undertreated alveolar hydatid disease.

14 patients who could be assessed, and the infection advanced to end-stage disease in $81 \%$ ( 17 of 21 cases). Considering all parameters, severe progression was confirmed in $95 \%$ of untreated cases. On the basis of the same criteria, none of the 13 treated cases showed severe progression. There was objective evidence of a favorable response in 10 patients $(77 \%)$ as indicated by regression in lesion size in five patients and negative in vivo viability assay for five. On the basis of each of these parameters, striking differences are observed between treated cases and the untreated controls.

Survival. In assessing the clinical effect of chemotherapy, we had an early favorable impression that survival time was extended through its use $[13,14,26]$. Among 21 patients who were never treated, the average survival time was 5.3 years postdiagnosis, and all of those patients have died.

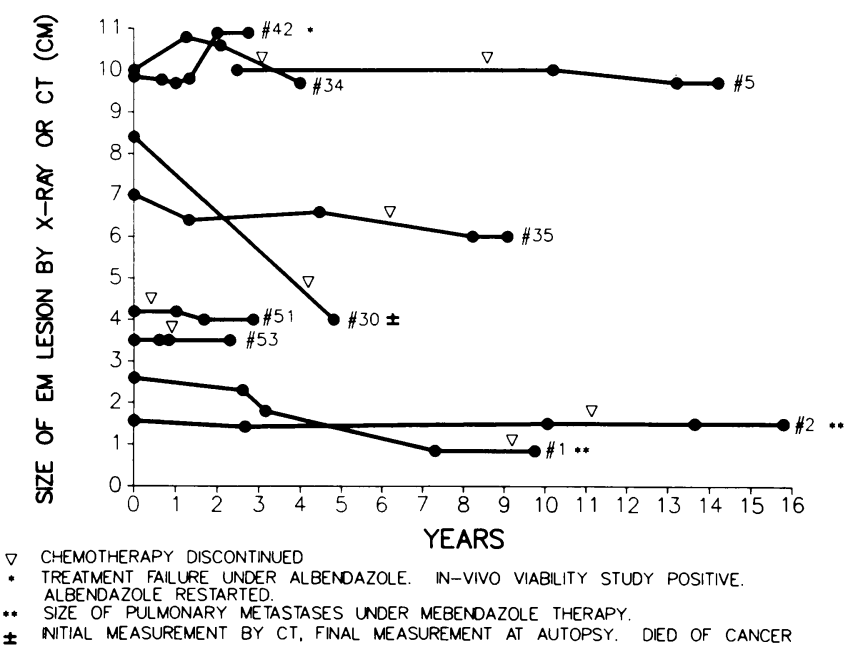

Figure 6. Size of the larval E. multilocularis (EM) lesion as determined by roentgenography or CT over time in treated alveolar hydatid disease. Note chemotherapy has been discontinued in each case except case 42 .

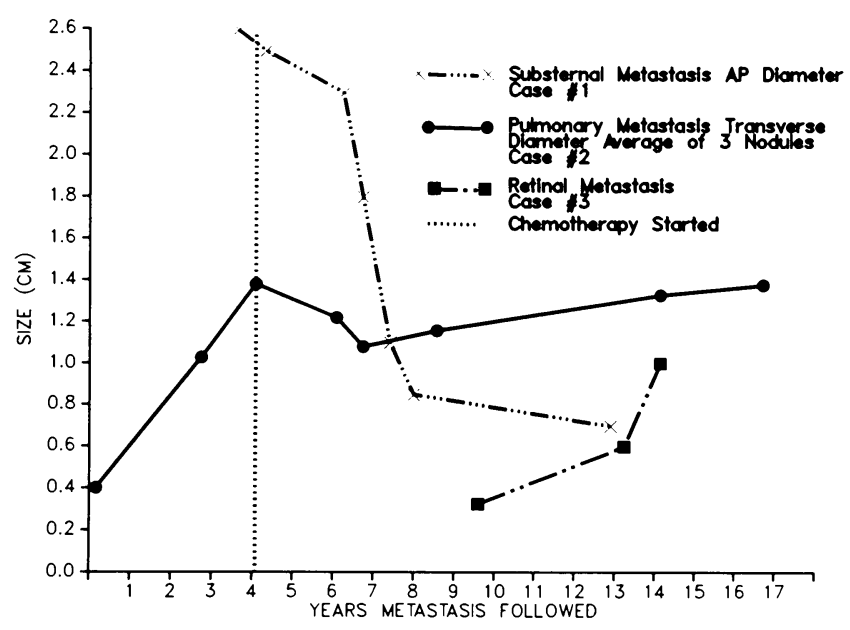

Figure 7. The effect of mebendazole therapy on the size of metastatic lesions of alveolar hydatid disease. The reduction in the size of the substernal metastasis of case 1 and the arrest of growth of the rapidly enlarging pulmonary metastases in case 2 are attributed to mebendazole therapy. $\mathrm{AP}=$ anteroposterior.

Among eight treated patients for whom AHD was diagnosed before 1981, survival time now averages 13.6 years (figure 8 ). Three patients who had advanced disease when chemotherapy was started are living, with survival time now averaging 18 years. Survival after the onset of end-stage disease was 0.6 years in the untreated cases and 15.7 years among patients in the treated group (figure 9). Because diagnosis has been made recently for most patients and their disease was identified at an earlier stage when the lesion was smaller, so

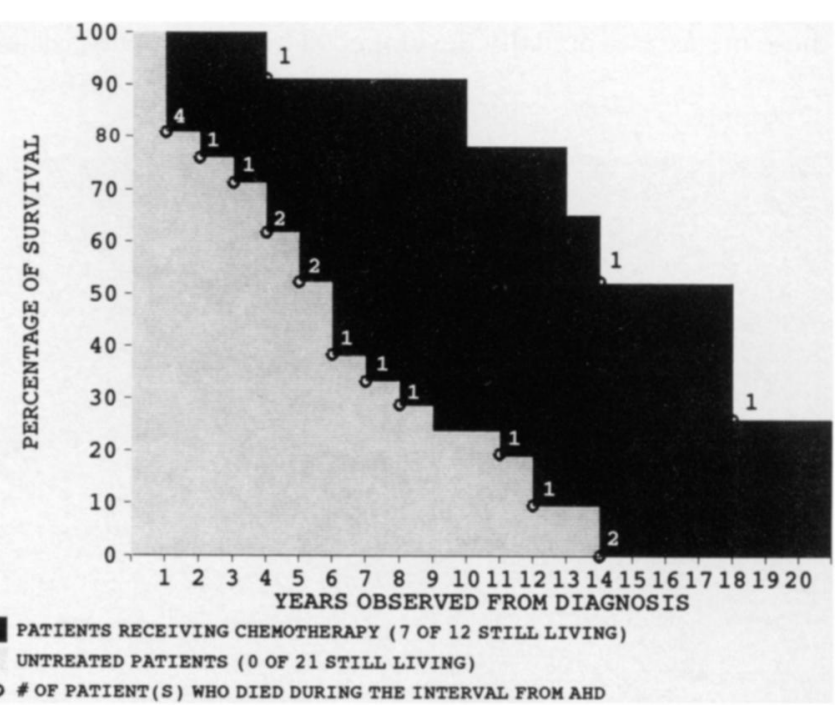

Figure 8. Comparative survival rates for 33 patients with alveolar hydatid disease. All untreated patients have died (average survival time, 5.3 years). The average survival time for eight treated patients who received the diagnosis before 1981 is 13.6 years and three of these are alive. 


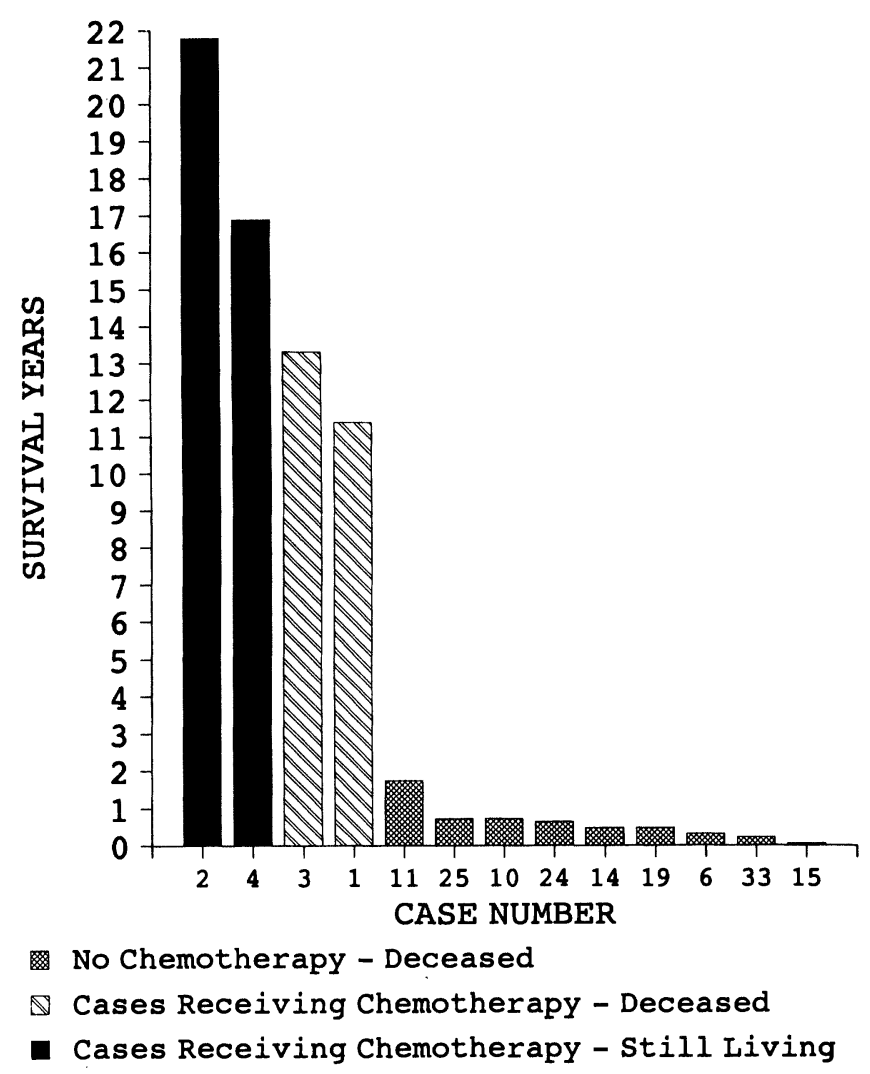

Figure 9. Survival after the onset of end-stage alveolar hydatid disease. Nine untreated patients survived only 0.6 years after onset of end-stage disease while four treated cases have survived 15.7 years, and two are alive.

little is known regarding the natural history of AHD that it is difficult to speculate on what the eventual survival time will be among the treated patients. Nevertheless, since all have remained asymptomatic and, with the exception of the one noncompliant patient, no enlargement of the lesion has been discerned for a period averaging nearly 5 years, we believe that they, as a group, can be expected to survive well beyond the untreated patients. The 5-year survival rate was $56 \%$ for the untreated group and $90 \%$ for the treated groups. The 10-year survival rate among untreated patients with a diagnosis of AHD before 1981 was $31 \%$ (five of 16 ) and $75 \%$ (six of eight) in the treated groups. Ammann et al. [23] also reported improved survival among 60 patients treated with long-term mebendazole therapy. The 5-year survival rate for these patients was $96 \%$, and at 10 years, $84 \%$. For untreated historical controls the 10 -year survival rate was $<10 \%$.

\section{Discussion}

The natural clinical course of untreated AHD has a wide spectrum of presentations. Some lesions appear to respond to host defenses and are spontaneously cured [6]. More charac- teristically, however, the course of untreated AHD is that of relentless growth with invasion of vital structures, resulting in obstruction of the inferior vena cava, major bile ducts, or portal blood flow; terminal anasarca often develops. A massive liver or a greatly distended abdomen due to ascites characteristically develops. Before we conducted our first chemotherapy trial in late $1974,67 \%$ (16 of 24) of our cases developed along this dreadful course (three of the first four patients treated with mebendazole had marked hepatomegaly when treatment was initiated). In others, fatal brain metastases or extensive pulmonary metastases occurred. One may consider this progressive but lingering fatal course to be the "classic" clinical course of active, untreated AHD.

The untreated AHD lesion consists of extremely dense fibrous tissue in which microcysts of the larval E. multilocularis are scattered [13]. The matrix is so dense that, as the lesion enlarges, blood vessels within the lesion are obliterated and a central zone of avascular necrosis characteristically develops (figures 3 and 4). In such lesions, the volume of parasite tissue is low, and all but a minute fraction of such tissue consists of nonliving, laminated membranes. Because the nonliving membranes as well as the dense fibrous tissue associated with AHD lesions would not be affected by a parasiticidal agent, reduction in lesion size, especially in the liver, may be minimal or may not occur at least during the first few years posttreatment. Where the larval E. multilocularis is rapidly proliferating and where less scar tissue develops, as in metastatic lesions, reduction in lesion size might be more likely to occur, as indeed was observed in each of two such patients (cases 1 and 2) who could be evaluated. Consequently, the arrest of growth of hepatic AHD lesions may well be all that is observed, even when the larval cestode is killed with therapy. Reduction in the size of the lesion should not necessarily be expected.

Distant metastases appear to be associated largely with advanced disease. Seven of the eight cases with metastases had advanced or end-stage disease when metastases were first observed. In Alaska, only two (20\%) of the last 10 new active cases of AHD diagnosed since 1975 occurred in patients who presented with symptoms, compared to $78 \%$ before that time. It appears that improved diagnostic and surveillance techniques have led to the diagnosis of AHD when the lesion is smaller $(5 \mathrm{~cm}$ vs. $13 \mathrm{~cm})$ and at an earlier average age (43 years vs. 59 years), thus permitting diagnosis and treatment before an advanced stage of disease has developed (which perhaps explains what appears to be a lower incidence of distant metastases in recent years).

The clinical course of the first four patients to receive chemotherapy in 1974 was significantly altered. Two of these patients eventually died 14 and 17 years after the diagnosis of late complications of AHD was made, but their course did not follow the classic course described above. Two patients are living 15 and 22 years after diagnosis with what we believe are dead lesions. These patients (nos. 2 and 5) have not 
received chemotherapy for an average of 6.2 years. Their CT studies have shown no growth of the lesions for 10 years and there has been extensive or complete calcification of their primary lesions. In case 2, 27 of 30 pulmonary metastases are totally calcified; no growth has been observed in the remainder for 17 years [12]. In case 5, the $\mathrm{EM}_{2}$ ELISA serology was strongly positive from 1975 to 1986 and on each of seven tests has been consistently negative since 1986 . Although serologies are often positive for patients with nonviable lesions because of retained laminated membranes, we believe the conversion to negative in this case is highly significant. These findings strongly suggest that the larval cestode is dead in each case.

After an intense study of the first nine inactive cases diagnosed [6], differentiation between an active AHD lesion and an inactive lesion in which the larval cestode has died has thus far not been difficult. Active lesions have been, without exception, of mixed density on CT [32]. They have been much larger in size and often were associated with symptoms, end-stage disease, or metastasis, whereas none of the inactive lesions have presented in association with these features. Among 26 cases identified as dead or inactive, all have had very densely calcified lesions and no demonstrable hypodense areas on CT. Of the lesions, $22(85 \%)$ were $\leqslant 2 \mathrm{~cm}$ in diameter, only one (3.8\%) was $>3 \mathrm{~cm}$ in diameter [6], and none was associated with symptoms; no patients developed end-stage disease or metastases. There is no evidence to suggest that any of the 13 treated cases presented in table 2 had inactive disease at the time of diagnosis: the average lesion size was $9.8 \mathrm{~cm}$ (range, $3 \mathrm{~cm}-26 \mathrm{~cm}$ ); the viability of the cestode was demonstrated by a positive viability assay with voles for six; three others had symptoms or end-stage disease; and viability was also evaluated in two cases by histopathologic examination of surgical tissue. The determination of viability was based on CT findings for only two of these patients (cases 5 and 53), and each had a typical mixed-density lesion, $4 \mathrm{~cm}$ and $10 \mathrm{~cm}$ in diameter, respectively. The lesion in case 53, discussed below, was the only one for which viability of the cestode could be seriously questioned. Thus far we have seen little reason to consider a lesion with typical mixed densities on CT as anything other than active. As improved screening methods permit diagnosis of active cases when the lesion is quite small, this issue may become difficult and require more study.

Vole-inoculation studies. We believe the vole-inoculation test represents the best and the only direct means of assessing viability of larval $E$. multilocularis. It is the standard by which other viability methods are measured. In animal studies Eckert [33] demonstrated extensive destruction with necrosis of larval $E$. multilocularis after administration of mebendazole therapy. Yet inoculations into animals with use of tissue from these severely damaged and apparently necrotic vesicles resulted in regrowth of the larval cestode, a finding that demonstrated that residual, viable parasitic tissues were present. Schantz et al. reported that albendazole (as with mebendazole) was not parasiticidal against $E$. multilocularis in animal hosts even when the hosts were medicated continuously for up to five months [34]. The failure of mebendazole to kill the parasite in such in vivo studies in laboratory animals is in part the basis for the widespread view that mebendazole may be parasitistatic but not parasiticidal $[15,16,35]$.

However, humans have a much more active immunologic response to E. multilocularis than do rodents, as evidenced by the absence of protoscolices together with the marked degree of necrosis and scarring associated with the lesion that develops in humans. The not-infrequent occurrence of spontaneous cure with death of the larval cestode also indicates a good host defense in humans [6]. Thus, the combination of an active immunologic response and the effect of chemotherapy could result in death of the parasite in humans but not in rodents.

The appearance of a typical E. multilocularis lesion on CT or an abdominal roentgenogram has been described as being of mixed density, with areas of calcification interspersed with radiolucent or hypodense areas $[32,36]$. This finding suggests that these lesions continue to proliferate peripherally, with healing in deeper tissues, death of the larval cestode, and increasing calcification. The laminated membranes in the microcysts are durable. In autopsy specimens, as well as in old, calcified, inactive lesions [6], the membranes have been observed in abundance despite the fact that the results of all viability assays indicated that the parasite was dead. When membranes are collected for viability assay, the percentage of microcysts that contain viable germinal tissue is not known but could be quite low. It is possible that among entire aliquots of membranes prepared for injection into voles there may be none with viable germinal cells. This may, in part, explain why proliferation fails to occur in some voles injected with membranes from viable lesions, as observed in cases $26,30,4, \mathrm{~W}, 5$, and others (table 1 ), and is the reason why three voles are routinely injected. Proliferation occurred in nine $(60 \%)$ of 15 voles injected with tissues from untreated patients, while it occurred in only three (9\%) of 34 voles injected with tissues from treated patients.

The favorable results among Alaskan patients, as reflected by the results of viability tests with voles, were not achieved in an important investigation by Eckert and Jacquier (unpublished). In vivo viability tests in gerbils were performed with use of tissue from 14 untreated Swiss patients. Positive results were obtained in 11 (79\%). Of tests on tissue from 12 patients who had been treated from 1 to 108 months with mebendazole ( 11 patients) or albendazole (one patient), 10 $(83 \%)$ were positive. The difference in the numbers of positive assays in the Swiss and Alaskan groups is striking but may be attributable largely to the duration of chemotherapy. The average period of treatment in Alaska was 70 months but was only 19 months in the Swiss experience. We seldom obtained negative test results unless the treatment had been 
Table 4. Albendazole therapy: results of in vivo viability assays and clinical assessments among compliant patients.

\begin{tabular}{|c|c|c|c|c|c|c|c|}
\hline \multirow[b]{2}{*}{$\begin{array}{l}\text { Case } \\
\text { no. }\end{array}$} & \multirow[b]{2}{*}{$\begin{array}{l}\text { Albendazole } \\
\text { therapy } \\
\text { (mo) }\end{array}$} & \multirow[b]{2}{*}{ Follow-up } & \multirow[b]{2}{*}{ Vole test } & \multicolumn{3}{|c|}{ Serial CT examinations $(\times 5)$} & \multirow[b]{2}{*}{$\begin{array}{l}\text { Results of } \\
\text { clinical } \\
\text { assessment }\end{array}$} \\
\hline & & & & $\begin{array}{l}\text { Initial } \\
\text { size }\end{array}$ & $\begin{array}{l}\text { Final } \\
\text { size of } \\
\text { lesion } \\
(\mathrm{cm})\end{array}$ & Changes in CT image & \\
\hline 39 & 2 & 6.6 & - & 4.3 & $\ldots{ }^{*}$ & & Excellent \\
\hline 51 & 3.75 & 4.7 & ND & $3.4 \times 4.5$ & $3.5 \times 1$ & $\begin{array}{l}\text { Much-reduced hypodense } \\
\text { areas; calcifications } \\
\text { more confluent and } \\
\text { dense }\end{array}$ & Very good \\
\hline 53 & 7 & 3.3 & ND & $2 \times 4$ & $1.5 \times 3.2$ & $\begin{array}{l}\text { Reduced hypodense areas; } \\
\text { calcifications more } \\
\text { confluent and dense; } \\
\text { decrease in size }\end{array}$ & Very good \\
\hline 60 & $3+9$ & 0.7 & $\begin{array}{c}+ \\
\text { (very weak) }\end{array}$ & 3.3 & $\ldots^{*}$ & & Excellent \\
\hline
\end{tabular}

NOTE. $\quad$ CT $=$ computed tomography; $\mathrm{ND}=$ not done.

* Lesion surgically resected.

given for $\geqslant 2$ years. Only three patients in the Swiss study had been treated for this long, and the test was negative for one of them.

The number of in vivo tests for which consistently negative results were obtained for mebendazole-treated patients (table 1), together with supporting clinical observations, offers convincing evidence that long-term mebendazole therapy has been parasiticidal. The limited number of vole tests performed for albendazole-treated patients and the shorter time of follow-up make the interpretation of the results for this group more difficult. However, in assessing these results, the following considerations should be kept in mind. The objective of these chemotherapy trials was, and continues to be, to learn as much as we can as quickly as possible about the therapeutic dosage of albendazole. We were aware that while patients were receiving mebendazole therapy, the parasite had survived as long as 48 months and that albendazole was often hepatotoxic; thus it was important to determine the shortest duration of administration of the drug for effective therapy. The first two vole tests gave negative results after only 2 and 3 months of therapy. More recent results indicate that the parasite, at least in case 60 , survived 3 months of treatment. The positive vole tests in cases 42 and 60 should not be viewed so much as reflecting the failure of albendazole therapy but rather that the minimum treatment time should be $>3$ months.

In view of the in vivo results together with the clinical observations on the four compliant patients who received albendazole, very impressive results were obtained that suggest that the long-term prognosis for these patients is excellent (table 4). In case 39 the negative vole test and negative postoperative serologies over 6.6 years are significant. The apparent reduced viability of the larval cestode with growth in only one of three injected voles in case 60 suggests that 3 months of chemotherapy had severely injured the parasite. In cases 51 and 53, no posttreatment tissue was available for in vivo studies. The clinical results, as reflected in the results of five serial CT studies, however, are very encouraging. In both cases, not only was there no growth of the lesion, but there has been a significant reduction in the amount of hypodense tissue; the calcifications have become more confluent and solid during the 3.3 and 4.7 years of observation. We are certain that in each case the lesion was active at the time chemotherapy was started because the pretreatment vole test in case 51 was positive and, in both cases, changes in the appearance on computed tomograms were observed over time. Had the lesion been dead, no change in appearance would have been expected. The advantages of a drug that is effective over months rather than years are so great that we feel continued emphasis on clinical trials with albendazole is justified.

We have presented our experience with albendazole for the treatment of AHD as well as evidence that it may be hepatotoxic in some cases [27]. Certainly, the need for close monitoring of all patients who receive the drug must be clearly recognized. There continues to be an urgent need to learn as much as possible from each new case of AHD. Our experience with this disease has persuaded us that postponing surgery adds little risk provided the patient is receiving appropriate chemotherapy. It is suggested that for all newly diagnosed cases, both of resectable and nonresectable lesions due to E. multilocularis, 4-6 months of preoperative therapy with albendazole be administered and be followed by viability studies on subsequent biopsy specimens or resected tis- 
sues. A drug-free interval of 1 week before surgery is suggested so that residual drugs in the tissue do not give false in vivo assay results (this precaution was taken in case 60 but not in previous studies). Although the therapeutic serum level of albendazole is not known, the dose should be adjusted to assure an albendazole sulfoxide serum level of $\sim 1,000 \mathrm{ng} / \mathrm{mL}$. Until therapeutic parameters are better defined, we feel that, following biopsy or resectional surgery, additional chemotherapeutic coverage with albendazole for a total of at least 12 months is advisable.

\section{Summary}

Most of these data suggest that the outcome of chemotherapy extends well beyond that of a favorable or parasitistatic effect. Some of the most convincing evidence for the successful killing of the larval E. multilocularis as a result of chemotherapy includes the following findings.

(1) Among 11 in vivo tests in six mebendazole-treated cases, the results of 10 consecutive tests performed since 1978 have been negative (table 1).

(2) In case 1 regression of the enlarging substernal metastasis from $26 \mathrm{~mm}$ to $8 \mathrm{~mm}$ (with negative results of a vole test on three occasions) occurred, with extended survival of the patient for 17 years.

(3) The abrupt arrest of growth of numerous pulmonary metastases in case 2 was associated with this patient's survival for 22 years, and recent $C T$ studies showed complete calcification of 27 of 30 pulmonary metastases as well as of the primary hepatic lesion.

(4) In case 4 the size of the hepatic abscess decreased without drainage, the surgical specimen appeared benign with loss of all matrix (figure 3), and the results of a vole test on the surgical tissue were negative. This patient is still living 17 years after the diagnosis was made, and mebendazole therapy has been discontinued for 4.5 years without evidence of recurrence.

(5) In case 5, followed for 15 years, a $7 \times 10$-cm hepatic lesion, initially proven to be active by the vole test, has demonstrated decreasing hypodense areas, increasing calcifications, and no growth on serial CT studies over a 10-year period. The $\mathrm{EM}_{2}$ serologies, consistently strongly positive for 10 years, have been negative on each of seven occasions since 1986 even though the patient has received no chemotherapy for 6.7 years.

(6) Among five patients treated with albendazole, vole viability assays were negative after 2 months of therapy for one patient; in two patients there was evidence of significant damage to the larval cestode after 1.5 and 3 months of therapy, respectively. For two other patients with resectable lesions who were treated with only albendazole, serial CT studies showed a decrease in the extent of radiolucent areas, an increase and confluence of calcifications, and no growth over 4 years. Although more time is required to fully assess this group of patients, the findings are consistent with a lethal effect of albendazole therapy.

(7) A comparative review of treated vs. untreated cases revealed striking differences. Among 21 untreated cases there was severe progression of disease in $95 \%$, end-stage disease developed in $81 \%$, and all patients have died after an average survival time of only 5.3 years. Among 13 treated cases, excluding the noncompliant patient, none showed severe progression or developed end-stage disease; in $77 \%$ there was objective evidence of a favorable response to therapy, and survival time is now 13.6 years (eight patients are still living and asymptomatic).

\section{Acknowledgments}

The authors are indebted to A. P. Lanier and the staff of the Arctic Investigations Program, Centers for Disease Control, Anchorage, Alaska, and to D. E. Trujillo and K. Hansen for active participation in and support of these studies and for technical assistance in the preparation of graphics. J. Eckert and P. Jaquier's permission to present the data on their experience with mebendazole therapy in Swiss patients is greatly appreciated. The authors are also grateful to the Janssen Pharmaceutical Corporation for its generosity in providing mebendazole and to the Smith Kline \& French Laboratories for supplying albendazole.

\section{References}

1. Zhuravlev VA. Operabel'nost' pri al'veokokkoze pecheni. Khirurgiia 1980;6:71-5.

2. Rausch R, Schiller EL. Hydatid disease (Echinococcosis) in Alaska and the importance of rodent intermediate hosts. Science 1951; 113:57-8.

3. Rausch RL, Wilson JF, Schantz PM. A programme to reduce the risk of infection by Echinococcus multilocularis: the use of praziquantel to control the cestode in a village in the hyperendemic region of Alaska. Ann Trop Med Parasitol 1990;84:239-50.

4. Gottstein B, Schantz PM, Wilson JF. Serological screening for Echinococcus multilocularis infections with ELISA [letter]. Lancet 1985;1:1097-8.

5. Lanier AP, Trujillo DE, Schantz PM, Wilson JF, Gottstein B, McMahon BJ. Comparison of serologic tests for the diagnosis and follow-up of alveolar hydatid disease. Am J Trop Med Hyg 1987;37:609-15.

6. Rausch RL, Wilson JF, Schantz PM, McMahon BJ. Spontaneous death of Echinococcus multilocularis: cases diagnosed serologically (by $\mathrm{EM}_{2}$ ELISA) and clinical significance. Am J Trop Med Hyg 1987; 36:576-85.

7. Heath DD, Chevis RAF. Mebendazole and hydatid cysts [letter]. Lancet 1974;2:218-9.

8. Braithwaite PA. Long-term high-dose mebendazole for cystic hydatid disease of liver: failure in two cases. Aust N Z J Surg 1981;51:23-7.

9. Bryceson ADM, Cowie AGA, MacLeod C, et al. Experience with mebendazole in the treatment of inoperable hydatid disease in England Trans R Soc Trop Med Hyg 1982;76:510-8.

10. Braithwaite PA, Allan RJ, Dawson M, Roberts MS, Watson TR. Cyst and host tissue concentrations of mebendazole in patients undergoing surgery for hydatid disease. Med J Aust 1983;2:383-4.

11. Gil-Grande LA, Boixeda D, Garcia-Hoz F, et al. Treatment of liver hydatid disease with mebendazole: a prospective study of thirteen cases. Am J Gastroenterol 1983;78:584-8. 
12. Wilson JF, Davidson M, Rausch RL. A clinical trial of mebendazole in the treatment of alveolar hydatid disease. Am Rev Respir Dis 1978; 1 18:747-57.

13. Wilson JF, Rausch RL. Alveolar hydatid disease: a review of clinical features of 33 indigenous cases of Echinococcus multilocularis infection in Alaskan Eskimos. Am J Trop Med Hyg 1980;29:1340-55.

14. Wilson JF, Rausch RL. Mebendazole and alveolar hydatid disease. Ann Trop Med Parasitol 1982;76:165-73.

15. Morris DL, Dykes PW, Marriner S, et al. Albendazole: objective evidence of response in human hydatid disease. JAMA 1985;253: 2053-7.

16. Luder PJ, Robotti G, Meister FP, Bircher J. High oral doses of mebendazole interfere with growth of larval Echinococcus multilocularis lesions. J Hepatol 1985; 1:369-77.

17. Okelo GBA. Hydatid disease: research and control in Turkana: III. Albendazole in the treatment of inoperable hydatid disease in Kenya -a report on 12 cases. Trans R Soc Trop Med Hyg 1986;80: 193-5.

18. Chinnery JB, Morris DL. Effect of albendazole sulphoxide on viability of hydatid protoscoleces in vitro. Trans $\mathrm{R}$ Soc Trop Med Hyg 1986;80:815-7.

19. Morris DL, Buckley J, Gregson R, Worthington BS. Magnetic resonance imaging in hydatid disease. Clin Radiol 1987;38:141-4.

20. Marriner SE, Morris DL, Dickson B, Bogan JA. Pharmacokinetics of albendazole in man. Eur J Clin Pharmacol 1986;30:705-8.

21. Rowley AH, Shulman ST, Donaldson JS, Schantz PM. Albendazole treatment of recurrent echinococcosis. Pediatr Infect Dis $\mathbf{J}$ 1988;7:666-7.

22. Todorov T, Vutova K, Petkov D, Balkanski G. Albendazole treatment of multiple cerebral hydatid cysts: case report. Trans R Soc Trop Med Hyg 1988;82:150-2.

23. Ammann R, Tschudi K, von Ziegler M, et al. Langzeitverlauf bei 60 Patienten mit alveolärer Echinokokkose unter Dauertherapie mit Mebendazol (1976-85). Klin Wochenschr 1988;66:1060-73.

24. Horton RJ. Chemotherapy of Echinococcus infection in man with albendazole. Trans R Soc Trop Med Hyg 1989;83:97-102.

25. Strohmaier WL, Bichler KH, Wilbert DM, Seitz HM. Alveolar echino- coccosis with involvement of the ureter and testis. $\mathrm{J}$ Urol 1990; 144:733-4.

26. Rausch RL, Wilson JF, McMahon BJ, O'Gorman MA. Consequences of continuous mebendazole therapy in alveolar hydatid disease: with a summary of a 10-year clinical trial. Ann Trop Med Parasitol 1986;80:403-19.

27. Wilson JF, Rausch RL, McMahon BJ, Schantz PM, Trujillo DE, O'Gorman MA. Albendazole therapy in alveolar hydatid disease: a report of favorable results in two patients after short-term therapy. Am J Trop Med Hyg 1987;37:162-8.

28. Rausch RL, Wilson JF. Rearing of the adult Echinococcus multilocularis Leuckart, 1863, from sterile larvae from man. Am J Trop Med Hyg 1973;22:357-60.

29. Furuya K. An established cell line of larval Echinococcus multilocularis. Int J Parasitol 1991;21:233-40.

30. Condon J, Rausch RL, Wilson JF. Application of the avidin-biotin immunohistochemical method for the diagnoses of alveolar hydatid disease from tissue sections. Trans $\mathbf{R}$ Soc Trop Med Hyg 1988;82:731-5

31. Smyth JD, Barrett NJ. Procedures for testing the viability of human hydatid cysts following surgical removal, especially after chemotherapy. Trans R Soc Trop Med Hyg 1980;74:649-52.

32. Didier D, Weiler S, Rohmer P, et al. Hepatic alveolar echinococcosis: correlative US and CT study. Radiology 1985;154:179-86.

33. Eckert J, Barandun G, Pohlenz J. Chemotherapie der larvalen Echinokokkose bei Labortieren. Schweiz Med Wochenschr 1978;108: 1104-12.

34. Schantz PM, Brandt FH, Dickinson CM, Allen CR, Roberts JM, Eberhard ML. Effects of albendazole on Echinococcus multilocularis infection in the Mongolian jird. J Infect Dis 1990;162:1403-7.

35. Woodtli W, Bircher J, Witassek F, Eckert J, Wüthrich B, Ammann $\mathrm{RW}$. Effects of plasma mebendazole concentrations in the treatment of human echinococcosis. Am J Trop Med Hyg 1985;34:754-60.

36. Thompson WM, Chisholm DP, Tank R. Plain film roentgenographic findings in alveolar hydatid disease-Echinococcus multilocularis. AJR Am J Roentgenol 1972;1 16:345-58. 